University of Michigan Law School

University of Michigan Law School Scholarship Repository

1916

\title{
Performance of Legal Obligation as a Consideration for a Promise
}

John B. Waite

University of Michigan Law School

Available at: https://repository.law.umich.edu/articles/663

Follow this and additional works at: https://repository.law.umich.edu/articles

Part of the Contracts Commons, Legal Remedies Commons, and the State and Local Government Law Commons

\section{Recommended Citation}

Waite, John B. (1912-1951). "Performance of Legal Obligation as a Consideration for a Promise." Mich. L. Rev. 14, no. 6 (1916): 480-4.

This Response or Comment is brought to you for free and open access by the Faculty Scholarship at University of Michigan Law School Scholarship Repository. It has been accepted for inclusion in Articles by an authorized administrator of University of Michigan Law School Scholarship Repository. For more information, please contact mlaw.repository@umich.edu. 
The Performance of a Leegat, Obligation as Considiration for a PromISE.-At a time when the true reasonableness of the common law and its responsiveness to the actualities of life are under criticism, it is interesting to find several cases, within the past year,. 
affirming the old rule that performance of a legal duty is not consideration for a promise. In Vance v. Ellison, (W. Va.) 85 S. E. 776 , suit was brought to enjoin the enforcement of a deed of trust executed by plaintiff to defendant, to secure payment of $\$ 1000$ promised for legal services. It was admitted that when the deed was executed the defendant was already bound by a written contract to perform them for $\$ 500$. Upon this showing the court held the deed to be without consideration, saying, "The doing of what one is already bound to do does not constitute good consideration for a promise." The same conclusion, on very similar circumstances was. reached in Moir v. Morris, (Ore.) I54 Pac. II7, (Jan., I916) and in Village of Seneca Falls v. Botsch, I 49 N. Y. Supp. 320. In Benedict v. Greer-Robbins Co., 26 Cal. App. 468, I47 Pac. 486, it was held that payment of a part of money due under a conditional sale contract, was not such consideration for an agreement to extend the contract as would deprive the vendor of his right to retake the property sold, before the expiration of the extension.

The rule that payment of money already due is not consideration for a promise induced by it is thoroughly established. Lord BLACKBURN said of the rule that in his opinion it developed originally from a mistake. Foakes v. Beer, 9 App. Cas. 605. This same view is taken by Professor AMrEs, who implies that its application has been a disappointment to the reasonable expectations of business men. Two TheorIes of Consideration, i2 Harv. LaW REV. 515, 52I. It has been changed by statute in a number of states, but it has been repudiated by judicial action in only two jurisdictions, Mississippi and New Hampshire. Clayton v Clark, 74 Miss 499 ; Frye v. Hubbell, 74 N. H. 358. Even Lord BLACKBURN felt himself bound to follow the rule, and Mr. Justice PoTrER, delivering the opinion in Jaffray v. Davis," 124 N. Y. I64, said that although the courts in following the rule "have rarely failed upon any recurrence of the question to criticise and condemn its reasonableness, justice, fairness and honesty, [yet] no respectable authority that $I$ have been able to find has, after such unanimous disapproval by all the courts, held otherwise. *** The steadfast adhesion to this doctrine by the courts, in spite of the current of condemnation of the individual judges of the court, and in the face of the demands and conveniences of a much greater business and more extensive mercantile dealings and operations, demonstrates the force of the doctrine of stare decisis." Trombley v. Klersey, I4r Mich. 73; Sands v. Gilleran, I44 N. X. S. 337; Estate of Casner, I Cal. App. I45.

If it be true that the rule is really unjust and harmful, and is retained only by the operation of the doctrine of stare decisis, criticism of the law in general, as independent of justice and as obsolete, is not wholly-without reason. It seems possible, however, that the courts may have "been, albeit intuitively and unconsciously, actuated by some other motive than the doctrine of stare decisis in holding to the rule.

There is no particular reason for applying that doctrine so vigorously in these cases. The rule is not one of property; indeed it is not one on which the promisor could allege a reliance in any event. To do so would be, in itself, an admission of fraud on his part,-a confession that he had made a promise which he knew to be legally unenforcible, and which he did not 
intend to keep, in order to induce an action, of value to him, on the part of the promisor. Its repudiation, then, would affect no rights; neither would it be in violation of any theory of the law. Even Br,AcKsTone, in declaring the eternal immutability of law as once declared, admitted that a rule which had been unreasonable at its inception might be repudiated, as being not law. Despite this the rule has been consistently maintained.

In its more general form of statement, the rule has even met with comparatively little criticism. It has been departed from wherever opportunity offered, and courts have seized such opportunity with avidity, but, with the exception already noted and a few sporadic cases, all departure can be logically ascribed to the fact that there really is a consideration-that the promisee has done something other than his legal obligation required.

The obligation created by a prior contract is not to do the thing expressly set forth in the agreement, but to do that or else to pay damages for not doing it. Even though "legal obligation" be converse to the right rather than to the remedy, yet when a right is conferred by agreement, it is fair to presume that the form of the remedy was in contemplation of both parties as determining the extent of the right so conferred, and; hence, indirectly, of the obligation. The remedy has been so long confined to a money recompense only, that undoubtedly a contractor relies on the fact that if unforseen obstacles to the performance as expressed should arise, he has a legal escape therefrom by payment of all damage resulting from non-performance in form. The truth of this is not demonstrable; but at least it is pragmatically true, and if it be assumed, it furnishes a logical ground of distinction of certain cases. Mr. Justice HocMIs, in discussing the law of contract, takes this view and says, in effect, that all promises are reducible ultimately to an assurance that the promisor will be answerable in damages if the thing promised shall not come to pass. The Connaron IAw. See also Chellis $\nabla$. Grimes, 72 N. H. I05. In the case of Frye v. Hubbell, 74 N. H. 358, the court in discussing the rule that performance of an obligation is not consideration, says, "The confusion arises from a failure to distinguish between legal and moral obligations. One may be morally bound to do precisely in terms as he agrees; but he is legally bound to do, as a practical proposition, whatever the theory may be, only what he can be compelled by law to do. The common law does not compel men to do as they agree. It gives damages for failure to perform legal or contractual duties but except in a few instances only can the specific performance of the contract be enforced." The court then proceeds to demonstrate that the maker of a promissory note is not obligated by law to pay the note, but that only damages for the non-payment are recoverable. This may be true in theory, but practically the recovery is an enforcement of payment of the note. The damages recovered and the amount due on the note are too nearly identical for a real distinction to be possible. Hence, in such cases, the person owing a debt has no choice but to pay it whether payment be made in forma or under the name of damages. Conversely, the creditor receives by voluntary payment to him, nothing other, save in name, than he would have received through the action of the law.

- But when, on the other hand, the debtor is in a position to go into bank- 
ruptcy, the law does give him a real option as to his course of action. He may pay his debt according to the form of his obligation, or he may be discharged from it by proceedings in bankruptcy. When he does pay his debt, under such circumstances, he really, not merely nominally, does something which he is not legally bound to do; he foregoes his right to an absolutely legal escape from paying according to the exact terms of his agreement. This forbearance to exercise an option is generally held to be a consideration for a promise, though it is not always so expressed. Melroy v. Kemmerer, 218 Pa. 38I, II L. R. A. (N. S.) IoI8, 67 Atl. 699; Engbretson v. Seiberling, I22 Iowa 522, I0I Am. St. Rep. 270; Frye v. Hubbell, 74 N. H. 358

Such is also the fact in respect to contracts to do something other than the payment of money. In these instances the contractor has two possible courses of action, either one of which will absolutely and effectually discharge his obligation. He may carry out his agreement according to its express terms, or he may pay damages, and the choice lies with him. Many cases hold that performance as expressed will support a contract. The case of Lattimore v. Harsen, I4 Johns (N. Y.) 330, arose out of a suit to enforce a promise given in consideration that the promisee would complete certain work which he was already under contract to do. The court sustained the action, saying, "By the former contract, the plaintiffs sulijected themselves to a certain penalty for the non-fulfillment, and if they chose to incur this penalty they had a right to do so. *** Here was a sufficient consideration for this promise." In Linz v. Schuck, I06 Md. 220, the court based a similar holding on the ground that the original contract had been mutually rescinded, and the doing of the work was a new consideration for the new promise. Agel v. Patch Manufacturing Co., 77 Vt. I3. "The prevailing rule seems to be, that such a promise is valid, as an abandonment of the old contract and the creation of a new contract." 30 AMs. \& ENG. ENCYc. OF LAw, II97. To the contrary, see Galway v. Prignano, I34 N.'Y. Supp. 57I; McQuaid v. Bonghman, 167 Ill. App. 430. It is impossible, however, by any devious route of logic to avoid the fact that the only consideration for the defendant's promise to pay is, after all, the doing of exactly what the plaintiff nad already contracted to be liable for. Since these decisions are so well established it seems fair to assume that underlying all forms of expression, the real consideration is the plaintiff's forbearance to exercise the other choice to which he was entitled.

Where a particular duty is imposed by law for the public good, there is ordinarily only one mode by which the person owing the duty can free himself from its obligation, namely, performance according to the terms expressed. A witness, for instance, within the jurisdiction of the court can not free himself from the obligation of testifying by the payment of damages nor in any other way. And his giving of testimony is not consideration for a promise. Collins v. Godefroy, I Barn \& Ad. 950. So the obligation of marital duties is not subject to satisfaction by anything except performance; although circumstances may be such as to remove the obligation itself. Accordingly we find that tha performance of such duties by one who has no 
right to relief therefrom, is not consideration for a promise. In re Kressler's Estate, I43 Pa. 386; Merrill v. Peasley, 146 Mass. 460 . But performance when the obligation might have been legally removed has been held a consideration. Moayon v. Moayon, Ir 4 Ky. 855, ro2 Am. St. Rep. 303; Phillips v. Meyers, 82 Ill. 67, 25 Am. Rep. 295.

The duties of public officers, although in form contractual, are primarily imposed by law, and it is uniformly held that the performance of such duties. is not consideration for a contract. City of Rochester v. Campbell, III N. E.. 420 , (Indiana). The surrendering of property wrongfully possessed has. also consistently been held not to constitute consideration. It might be noted, parenthetically, that while the replevin statutes of most states allow the defendant to retain possession of the property by indemnifying the sheriff, this seems not to have been regarded as giving the defendant a real option to render the property or its value as was the case in detinue. Johnson v. Boehme, $66 \mathrm{Kan} .72,97$ Am. St. Rep. 357; Flall v. Law etc. Trust Co., 22 Wash. 305: But see, Single v. Schnelider, 24 Wis. 299.

It seems, then, that the only instances in which the courts appear to havedeparted from the rule that doing. what one is already legally bound to do is not consideration, are in fact instances in which the thing done was not what the doer was obliged to do, but, rather, one of the things the choice of which lay with him. There was therefore, logically even though not expressly, a very real consideration, and the cases are not departures from the rule. In all other cases, the courts have rigidly adhered to the rule.

The writers both judicial and lay, who criticise this, admit frankly that the rule is perfectly logical; they ascribe the desirability of a departure from it to the practical advantage which business generally would derive. The Turk who, in accord with custom, "tips" his postman and telegraph messenger for performing their respective duties undoubtedly finds a very practical benefit in so doing-there would otherwise be a discommoding number of perfectly valid excuses for delays and mistakes. For the law to enforce promises of additional compensation for the doing of one's legal duty, would be to admit that its remedies, its enforcement of rights, are not equal to the practicable possibilities. This may be the fact, but it is not so in the necessary theory. Legal sanction for such promises would tend very probably to. increase the refusal to perform, for the sole purpose of exacting an unconscionable increase of compensation for performance. No one can say with any certainty why the courts have so consistently followed a rule, so generally condemned as unreasonable, and to which no established rights constrain: them. Criticism of the law as unresponsive to the reality of human relations is, in this instance, sound if there be no good reason for such a course. But the courts would not arbitrarily remain subject to such just criticism, and it is therefore possible that, sub-consciously at least, courts have so acted through fear of substituting a "tipping system" of unconscionable inducement. in the place of legal remedies.

J. B. W. 